\title{
Common Viral Infections in Children after Kidney Transplantation
}

Author (s)

Affiliation

(s)

Article

Information

\section{Thanaporn Chaiyapak}

Mahidol University, Siriraj Hospital, Faculty of Medicine, Department of Pediatrics, Division of Nephrology, Bangkok, Thailand

Article Type: Invited Review

Article Group: Pediatric Nephrology
Received: 05.07.2021

Accepted: 30.07 .2021

Available Online: 29.08.2021

Cite this article as: Chaiyapak T. Common Viral Infections in Children after Kidney Transplantation. J Pediatr Acad 2021; 2: 43-51.

\section{Abstract}

Viral infection is a common complication among pediatric kidney transplant recipients, causing significant morbidity and mortality. Sources of viral infection in pediatric transplant recipients include donor allografts, blood products, and latent virus reactivation. Major risks of viral infection include kidney donor-derived, nosocomial and community-acquired infections as well as the immunosuppressive status of recipients. Clinical presentations are variable, ranging from no symptoms to severe disease. Preventive strategies such as immunization and pretransplant-specific viral screening in both donors and recipients are performed before kidney transplantation to identify high-risk recipients. Posttransplant prophylactic strategies include universal prophylaxis and preemptive therapy. Universal antiviral prophylaxis is required for high-risk cytomegalovirus (CMV)-mismatch pediatric recipients. Preemptive therapy requires the administration of sensitive viral surveillance tests to detect subclinical viral infections to optimize individualized immunosuppressive drugs and initiate antiviral therapy. This review summarizes current knowledge regarding common viral infections in children after kidney transplantation, including CMV, BK polyomavirus, Epstein-Barr virus (EBV), and coronavirus disease 2019 (COVID-19), which is caused by severe acute respiratory syndrome coronavirus 2 (SARS-CoV-2).

Keywords: Viral infection, post kidney transplantation, pediatrics

Correspondence: Thanaporn Chaiyapak, Mahidol University, Siriraj Hospital, Faculty of Medicine, Department of Pediatrics, Division of Nephrology, 2 Wanglang Road, Bangkoknoi, Bangkok 10700, Thailand.

E-mail: thanaporn0611@gmail.com 


\section{Introduction}

Posttransplant infection is a major cause of hospitalization among pediatric kidney transplant recipients. ${ }^{1}$ Viral infection is a common opportunistic infection after kidney transplantation. The consequences of viral infection in transplant recipients include direct effects, such as invasive organ-specific disease, or indirect effects from immune processes, resulting in allograft rejection and opportunistic infections. ${ }^{2,3}$ These effects are associated with significant morbidity and mortality in pediatric kidney transplant recipients. Risk of viral infection depends on the specific viral status of donors and recipients, complete or incomplete pretransplantation vaccination, types of immunosuppressive drugs and routine antiviral prophylaxis regimens. ${ }^{3,4}$ Regular viral surveillance should be routinely performed for the early detection and early management. 5,6 Pediatric kidney transplant recipients who do not undergo regular viral surveillance are at risk of developing severe viral disease. $^{7}$

\section{Highlights}

- The consequences of viral infection in transplant recipients include direct effects, such as invasive organspecific disease, or indirect effects from immune processes, resulting in allograft rejection and opportunistic infections.

- Risk of viral infection depends on the specific viral status of donors and recipients, complete or incomplete pretransplantation vaccination, types of immunosuppressive drugs and routine antiviral prophylaxis regimens.

- The initial treatment for viral infection post kidney transplantation is reducing immunosuppressive therapy, but doing increases the risk of allograft rejection.
Several viral infections may

occur post kidney transplantation. These infections may be caused by reactivation of latent viruses due to immunosuppression or transmission from a donor allograft or blood products; such viruses include cytomegalovirus (CMV), BK polyomavirus, EpsteinBarr virus (EBV), hepatitis $B$ virus (HBV), hepatitis $C$ virus (HCV), herpes simplex virus (HSV), varicella zoster virus (VZV), and human immunodeficiency virus (HIV). Moreover, community-acquired infections such as respiratory syncytial virus (RSV), adenovirus, influenza and coronavirus disease 2019 (COVID-19), which is caused by severe acute respiratory syndrome coronavirus 2 (SARS-CoV-2). may also occur. This review summarizes the current knowledge regarding common viral infections that occur after kidney transplantation in children, including CMV, BK polyomavirus, EBV, and SARS-CoV-2 infections.

\section{Timetable of and general therapy for viral infection post kidney transplantation}

The pattern of viral infection after kidney transplantation changes over time and depends on 2 major factors: ${ }^{3,4}$ 1) recipient exposure to kidney donor-derived, nosocomial and community-acquired infections; and 2) the immunosuppressive status of the recipient.

\section{Phase I: 1 month post kidney transplantation}

Viral infection in the early post kidney transplantation period is uncommon and is generally associated with donor-derived viral infection, which can be caused by latent viruses in donor allografts or active donor-derived infection, such as HSV and HIV infections. ${ }^{3,4}$ Children with previous HSV may have early reactivation within after the cessation of antiviral prophylaxis.,12 Most cases of polyomavirus-associated nephropathy (PVAN) occur in the $1^{\text {st }}$ year post kidney transplantation. ${ }^{2}$ In addition, community-acquired respiratory viruses such as influenza, parainfluenza, RSV, adenovirus and foodborne gastroenteritis due to rotavirus and norovirus are still common and occur at any time of exposure..$^{2,3}$

\section{Phase III: More than 6-12 months post kidney transplantation}

Although the risk of late-onset infection decreases at more than 6-12 months post kidney transplantation due to immunosuppressive drug weaning, communityacquired viral infections, including respiratory viral infections and foodborne gastroenteritis, can still occur. ${ }^{2,3}$ In addition, reactivation of latent viral infections can occur, especially during treatment for allograft rejection. $^{2}$

\section{General therapy}

In general, the initial treatment for viral infection post kidney transplantation is reducing immunosuppressive therapy, but doing increases the risk of allograft rejection. ${ }^{3}$ Furthermore, individualized antiviral therapy and diagnosis of other coinfections are still required based on specific viruses and the severity of viral infection.

\section{Cytomegalovirus (CMV)}

$\mathrm{CMV}$ is a member of the betaherpesvirus family and is the most common viral infection and cause of morbidity and mortality in both adults and pediatric transplant recipients. ${ }^{8}$ 


\section{Definitions}

CMV in transplant recipients is classified into CMV infection or CMV disease. CMV infection is defined as CMV isolation or the detection of proteins (antigen, $\mathrm{Ag}$ ) or nucleic acids in any body fluid or tissue specimen, such as plasma, whole blood, cerebrospinal fluid (CSF), bronchoalveolar lavage (BAL) fluid, urine or tissue, regardless of symptoms. ${ }^{13,14} \mathrm{CMV}$ disease is defined as CMV replication accompanied by symptoms. ${ }^{14} \mathrm{CMV}$ disease is classified further into either CMV syndrome or tissue-invasive CMV disease. CMV syndrome is defined as CMV infection with at least 2 of the following: (i) fever $>38^{\circ} \mathrm{C}$ for at least 2 days; (ii) new or increased malaise or fatigue; (iii) a white blood cell count (WBC) $<3,500$ cells/cu.mm. on 2 separate measurements at least 24 hours apart if the initial WBC was $>4,000$ cells/cu.mm or a WBC decrease of $>20 \%$ if the initial WBC was $<4,000$ cells/cu.mm.; (iv) atypical lymphocytes $>5 \%$; (v) thrombocytopenia with a platelet count $<100,000$ cell/ cu.mm. if the initial platelet count was $>115,000$ cells/ cu.mm. or a platelet count decrease of $>20 \%$ if the initial platelet count was $<115,000$ cells/cu.mm.; or (vi) elevation of hepatic aminotransferase to 2 times the upper limit of normal. ${ }^{14}$ Tissue-invasive CMV disease is associated with specific organ involvement, such as pneumonitis, colitis, hepatitis, retinitis, encephalitis, nephritis, myocarditis, or pancreatitis. ${ }^{4,13}$

\section{Epidemiology and risk factors}

The main risk factor for CMV deoxyribonucleic acid in blood (DNAemia) is the CMV serostatus of donors (D) and recipients (R). CMV recipient positivity $(R+)$ is indicative of previous infection and immunity. ${ }^{15,16}$ More children than adults are CMV naïve or CMV recipient negative (R-), which implies that they have no history of CMV exposure prior to kidney transplantation and do not have immunity. Therefore, CMV mismatched (donorpositive recipient-negative, D+R-) recipients have the highest risk for primary CMV infection, which is more severe than secondary CMV infection, post kidney transplantation. ${ }^{4,15,17}$ Intermediate CMV risk is defined as CMV R+, which is associated with a substantial risk of secondary CMV infection due to either reactivation of latent CMV or superinfection (or reinfection). ${ }^{14,16}$ Other risk factors include an intense immunosuppressive drug regimen, especially one that stimulates $T$ celldepleting antibodies. ${ }^{3,16}$ A retrospective study in children demonstrated that children who received antithymocyte globulin for induction therapy developed CMV DNAemia within the first 3 months after cessation of universal antiviral prophylaxis compared with those who received anti-interleukin-2 (IL-2). ${ }^{12}$

\section{Clinical manifestations}

The clinical presentations of CMV infection and disease vary, ranging from no symptoms to fatal severe disease, and can be confused with those of other infections and allograft rejection. ${ }^{18}$ The clinical presentation of CMV syndrome is nonspecific and includes symptoms such as fever, anorexia, myalgia, and arthralgia. ${ }^{16}$ Laboratory results may show leukopenia and thrombocytopenia. ${ }^{16}$ Children with tissue-invasive disease may present with organ-specific involvement, such as pneumonitis, colitis, hepatitis, retinitis, encephalitis, nephritis, myocarditis, or pancreatitis. The most common system affected by tissue-invasive CMV disease is the gastrointestinal system, which can result in vomiting, abdominal pain, diarrhea, and gastrointestinal hemorrhage. ${ }^{10,19}$

Furthermore, CMV has indirect effects, including an increased risk of allograft rejection and suppression of host immunity that predisposes patients to opportunistic infections such as EBV and human herpesvirus 6 (HHV6) infections, fungal infections, and some bacterial infections. ${ }^{2,4}$

\section{Diagnosis}

\section{Pretransplant testing}

CMV IgG serology in both donors and recipients is recommended for the identification of recipients at high risk of CMV infection and can guide antiviral prophylaxis post kidney transplantation. 3,14 However, the passive transfer of CMV IgG from mothers to infants can produce false positive results in infants less than 1 year of age. ${ }^{3}$

\section{Posttransplant testing}

Quantitative CMV viral load: The diagnosis of CMV DNAemia is the presence of CMV DNA in whole blood or plasma. ${ }^{4,16}$ Currently, quantitative nucleic acid amplification testing (QNAT) in whole blood or plasma for CMV viral load is the gold standard for the diagnosis and monitoring of CMV DNAemia, but the CMV viral load threshold is controversial. ${ }^{14} \mathrm{~A}$ highly sensitive QNAT assay is suggested, which has a lower limit of quantification (LLOQ) $<200 \mathrm{IU} / \mathrm{ml} .{ }^{14}$ However, a $\mathrm{LLOQ}<10 \mathrm{IU} / \mathrm{ml}$ is too sensitive and may detect latent CMV DNA, which is not clinically significant. In contrast, a $L L O Q>1,000 \mathrm{IU} / \mathrm{ml}$ is too insensitive and is not recommended. ${ }^{14}$ Antigenemia assays, such as pp65 and pp67 antigen detection, and semiquantitative fluorescence assays are no longer recommended. ${ }^{2}$

Tissue biopsy: CMV tissue-invasive disease generally requires tissue histopathology for a definitive diagnosis. The presence of CMV inclusion or immunostaining is the gold standard for the diagnosis of CMV tissueinvasive disease. ${ }^{3}$ However, the presence of organspecific symptoms combined with the detection of CMV DNAemia is adequate for the clinical diagnosis of CMV tissue-invasive disease. ${ }^{16}$ In contrast, the absence of CMV DNAemia cannot exclude CMV disease in children who have organ-specific symptoms. ${ }^{14,16}$ The CMV viral load during CMV infection of the gastrointestinal tract or central nervous system (CNS) is generally lower than that at other sites. ${ }^{3}$ Tissue biopsy is still required in children who are treated with antiviral therapy and do not respond.

CMV serology: CMV seroconversion is defined as the presence of CMV IgG post kidney transplantation in CMV R- patients. The seroconversion rate in solid organ transplant patients is approximately $75 \%$ at 12 months post transplantation in patients receiving universal antiviral prophylaxis, and the detection of 
CMV IgG at 6 months post kidney transplantation is associated with a decreased risk of late CMV disease at 6-12 months post transplantation. ${ }^{20}$ However, CMV $\operatorname{lgM}$ and seroconversion of CMV IgG are not useful for the diagnosis of acute infection because of the delay in conversion. ${ }^{3}$

\section{Treatment}

According to the Third International Consensus Guidelines on the Management of Cytomegalovirus in Solid-organ Transplantation, the recommendation for children is based mostly on adult data. ${ }^{14}$ Ganciclovir is the primary antiviral agent to treat CMV disease by inhibiting CMV replication. ${ }^{8}$ Valganciclovir is a prodrug of ganciclovir that is also used for the treatment of asymptomatic CMV DNAemia. However, initial treatment of severe CMV disease with intravenous ganciclovir in children is still recommended. ${ }^{14}$ Once-weekly CMV surveillance is recommended to monitor response to antiviral therapy and discontinue therapy after CMV negativity by highly sensitive QNAT (LLOQ <200 IU/ml) 1 time or CMV negativity by non-highly sensitive QNAT (LLOQ >200 IU/ml) 2 consecutive times. ${ }^{14}$ A recent study demonstrated that a CMV viral load $<137 \mathrm{IU} / \mathrm{ml}$, as measured by a test calibrated to the World Health Organization (WHO) standard, is predictive of clinical response to antiviral treatment. ${ }^{21}$

In addition to antiviral therapy, reduction in immunosuppressive therapy is an important adjunctive therapy if possible. Conversion to mTOR inhibitors may be useful to reduce the risk of recurrent CMV DNAemia, especially in patients at high risk of CMV infection. ${ }^{14,22}$ There is no strong data supporting the use of CMV IgG and intravenous immune globulin (IVIG) in combination with antiviral therapy. 3,14

\section{Prevention}

Currently, there are 3 strategies for CMV infection prevention in pediatric kidney transplant recipients: universal prophylaxis, preemptive therapy, and the sequential approach, depending on risk. ${ }^{14}$ With universal prophylaxis, antiviral prophylaxis is provided to children at high risk of CMV infection, which is defined as $\mathrm{CMV} \mathrm{D}+\mathrm{R}$ - or receiving $\mathrm{T}$ cell-depleting antibodies, for 3-6 months post kidney transplantation.14 Although valganciclovir is widely used among adult kidney transplant recipients, pharmacokinetic data in pediatric patients are limited to only older children. ${ }^{23-25}$ Furthermore, the risk of DNAemia is highest during the 3 months after antiviral prophylaxis cessation, so surveillance needs to be continued during this time period. ${ }^{12,14}$

For preemptive therapy, antiviral therapy is started when QNAT detects CMV before the development of CMV disease. ${ }^{14}$ Unfortunately, the optimal CMV viral load threshold to initiate therapy is still controversial because of the variability in diagnostic tests. The sequential approach involves a short duration, typically 2-4 weeks, of antiviral prophylaxis, followed by regular CMV surveillance. ${ }^{14}$ Children with intermediate CMV risk $(R+)$ can receive universal prophylaxis, preemptive therapy or the sequential approach. ${ }^{14}$ Weekly surveillance for CMV DNAemia for at least 3-4 months post transplantation is recommended. ${ }^{20}$ Secondary antiviral prophylaxis might be advantageous in children with recurrent CMV DNAemia, but the proper duration is still unclear. ${ }^{14}$ Although there are several studies on and developments in CMV vaccines, they are mostly in phase I and phase II trials.

\section{Polyomavirus}

Polyomavirus is a small DNA virus. Primary infection in an immunocompetent host is subclinical or induces respiratory tract symptoms; subsequently, the virus becomes latent in renal tubular epithelial cells or the uroepithelium. ${ }^{26,27}$ The two well-known human polyomaviruses are polyomavirus hominis type 1 or $\mathrm{BK}$ virus $(\mathrm{BKV})$ and polyomavirus hominis type 2 or $\mathrm{JC}$ virus (JCV). The BK seropositivity rate in children less than 18 years of age is approximately $5-65 \%$ and in adults is more than $80 \% .^{28-30}$ Immunocompetent children are usually asymptomatic, but polyomavirus can reactivate after kidney transplantation and initially induce no symptoms but subsequently lead to PVAN in up to $10 \%$ of patients and graft loss in approximately $10-100 \%$ of patients. $3,31,32$

\section{Definition}

Polyomavirus infection is defined as serological or virological evidence of polyomavirus exposure regardless of viral replication or latency. ${ }^{31}$ Primary and secondary infections are detected in seronegative and seropositive individuals pre kidney transplantation, respectively. Polyomavirus disease is defined as evidence of polyomavirus in the tissue of the involved organ. ${ }^{31}$

\section{Epidemiology and risk factors}

The prevalence of PVAN ranges from 1.1 to $10.3 \%{ }^{31}$ Most PVAN is caused by BKV, although there are a few case reports of PVAN due to $\mathrm{JCV}^{33-36}$ The major presentation of JCV is CNS disease with no renal involvement. $^{3}$ The main risk factors for BK viremia and PVAN are intense immunosuppressive regimens, especially regimens including high-dose tacrolimus, high-dose mycophenolate mofetil (MMF), T celldepleting antibodies, and antirejection therapy. 2,26,31,37 Most PVAN occurs within the $1^{\text {st }}$ year of kidney transplantation due to intense immunosuppressive drug use. ${ }^{38,39}$ Retransplantation due to PVAN is also a risk factor for reinfection in a new allograft. $^{3}$

\section{Clinical manifestations}

The majority of recipients with polyomavirus infection are asymptomatic. ${ }^{2}$ Some children present with sterile pyuria, ureteral stenosis and hemorrhagic cystitis. ${ }^{2,8,35,40}$ Children with ureteral stenosis may present with signs of urinary tract obstruction or elevated creatinine levels. In addition, an acute or gradual decline in renal function is usually a common presentation of PVAN. ${ }^{2,8}$ Some children present with fever, but this is not the usual presentation and may mimic acute rejection or other infections. ${ }^{8}$ 


\section{Diagnosis}

Viral replication occurs in a usual sequence. After BKV reactivation, the virus initially replicates in renal tubular cells, leading to tubular damage and resulting in viruria. Subsequently, BKV enters peritubular capillaries, resulting in BK viremia, at a median of 4 weeks later. Finally, PVAN developed at a median of 4 weeks later. ${ }^{26}$

Urine cytology: Decoy cells include infected tubular and ureteral epithelial cells that can be observed on urine cytology and serve as a marker of high levels of urine BK DNA. Although urine decoy cells are used in screening for PVAN, the sensitivity, specificity, and positive predictive value (PPV) are only $66.7 \%, 88.6 \%$, and $11.7 \%$, respectively. ${ }^{41}$

Quantitative BK viral load in urine: The detection of a low BK viral load in urine commonly occurs in immunocompetent hosts without clinical consequences. ${ }^{42}$ However, a post-kidney transplantation urine BK viral load of $>107$ copies/ml is increasingly predictive of PVAN, although it is not highly specific. ${ }^{3,36}$ In addition, some patients with BK viruria do not develop $\mathrm{BK}$ viremia, and the detection of BK viruria is not cost efficient in a clinical setting. ${ }^{43}$

Quantitative BK viral load in plasma: A BK viral load $>10,000$ copies $/ \mathrm{ml}$ detected by polymerase chain reaction (PCR) quantification has a good PPV and $93 \%$ specificity for PVAN. ${ }^{26,44,45}$

Allograft biopsy: Allograft biopsy should be performed when the BK viral load in plasma is $>10,000$ copies $/ \mathrm{ml}$ with or without elevated creatinine because of its high association with PVAN. ${ }^{3,26}$ Histopathological findings include interstitial inflammation in early infection that progresses to tubular atrophy and interstitial fibrosis. ${ }^{46,47}$ In addition, allograft rejection may coexist with PVAN. ${ }^{48-50}$ The definitive diagnosis of PVAN includes the presence of viral inclusion bodies, the detection of simian virus 40 (SV40) on staining or in situ hybridization for BK virus genetic sequences, but the lesions of PVAN are usually focal and easily missed. ${ }^{3,26,46,47}$ Presumptive PVAN is defined as the presence of a BK viral load $>10,000$ copies $/ \mathrm{ml}$ with no evidence of polyomavirus in allograft tissue. ${ }^{26}$

\section{Treatment}

Since there is no specific antiviral therapy for polyomavirus infection, the mainstay of treatment is a reduction in immunosuppression when there is evidence of viral replication, especially when the BK viral load is higher than 10,000 copies $/ \mathrm{ml}^{2,26,51}$ The goal of immunosuppressive drug reduction is to restore immunity against polyomavirus, but this increases the risk of acute rejection, which is associated with poor renal outcomes. ${ }^{52}$ There is currently no consensus protocol for immunosuppressive reduction. According to recent guidelines, ${ }^{26,51}$ a common practice is to half or withdraw the antimetabolite drug (azathioprine or MMF) and to reduce the calcineurin inhibitor target level. In addition, switching from the antimetabolite drug to leflunomide is also commonly used. Leflunomide has both immunosuppressive and antiviral activities. $^{53,54}$ To date, there are limited data on the use of fluoroquinolones and IVIG for treating PVAN. ${ }^{3,26}$ Treatment for cooccurring PVAN and acute rejection remains unclear. ${ }^{55}$

\section{Prevention}

Currently, there is no single standard strategy to prevent $\mathrm{BK}$ reactivation. ${ }^{26} \mathrm{BK}$ viral load monitoring and early identification of BK viremia allow early intervention to prevent progression to PVAN. According to recent guidelines, QNAT to detect the BK viral load in plasma is the main screening method and should be performed monthly for the first 3-6 months and then every 3 months for the first year post kidney transplantation, when there is an unexplained elevation in the creatinine level, and after treatment for acute rejection. ${ }^{26,31}$

\section{Epstein-Barr virus (EBV)}

EBV is in the gammaherpesvirus family. ${ }^{8}$ Most children in developing countries are infected with primary EBV before 5 years of age..$^{56,57}$ In contrast, EBV infection in developed countries occurs in late adolescence or adulthood. ${ }^{56,57}$ After primary infection in an immunocompetent host, EBV remains latent in lymphocytes and reactivates due to immunosuppression after kidney transplantation. ${ }^{8}$ However, the majority of symptomatic EBV infections post kidney transplantation are due to EBV-mismatched recipients (EBV D+R-). ${ }^{8,57}$ EBV is detected in more than $90 \%$ of patients with early posttransplant lymphoproliferative disorders (PTLDs) after kidney transplantation and is an uncommon but fatal complication. , $3,57,58$ The role of EBV in late PTLDs is uncertain.

\section{Epidemiology and risk factors}

Primary EBV infection usually occurs within the 1st year post kidney transplantation. ${ }^{3}$ The majority of EBV-naïve (EBV R-) patients are pediatric patients, so they are at risk of developing primary infection and subsequently early PTLDs than adults. ${ }^{57}$ The major risk factor for EBV infection is intense immunosuppression, especially in patients receiving $\mathrm{T}$ cell-depleting antibodies and OKT3 ${ }^{2,8}$ A persistently high level of EBV DNAemia post kidney transplantation may indicate a risk of PTLD. ${ }^{3,59}$

PTLD is more common in children (up to 20\%) than adults (less than 1\%) post kidney transplantation and can present with a bimodal pattern of onset in the first year post transplant; it can also present late, at 5-10 years post transplantation. , $^{3,60-62}$ Risk factors for early PTLD (<12 months) include primary EBV infection, young recipient age, and polyclonal antilymphocyte antibody use..$^{57,62-65}$ In contrast, risk factors for late PTLD (>12 months) include duration of immunosuppression and older recipient age..$^{57,62-65}$

\section{Clinical features}

Children with EBV DNAemia are usually asymptomatic. The clinical manifestation of EBV disease (nonPTLD) includes infectious mononucleosis, including fever, exudative tonsillitis, lymphadenopathy, hepatosplenomegaly and atypical lymphocytosis. ${ }^{2,57}$ Some children present with organ-specific symptoms such as hepatitis, pneumonitis, pancreatitis, meningitis, 
leukopenia, or thrombocytopenia. 2,57 However, some of these clinical manifestations are similar to those associated with PTLDs. Patients with graft dysfunction as well as EBV DNAemia should be evaluated for PTLDs and graft rejection. ${ }^{3}$

PTLDs can affect either allografts or other organs; the clinical presentation is based on organ involvement and can include abdominal pain or mass, gastrointestinal bleeding, obstruction, perforation, hepatic or pancreatic dysfunction, headache, other CNS disease, allograft dysfunction, or pulmonary nodules or infiltration. ${ }^{2,3}$ In addition, some children present with nonspecific symptoms, including unexplained fever and weight loss. ${ }^{3}$ The definitive diagnosis of PTLDs requires tissue biopsy. ${ }^{8}$

\section{Diagnosis}

\section{Pretransplant testing}

EBV serology: Screening by EBV serology in both donors and recipients is recommended for the prediction of EBV DNAemia risk. ${ }^{57}$ Antiviral capsid antigen (VCA) IgG and anti-Epstein-Barr virus nuclear antigen (EBNA) IgG are recommended for screening tests. However, the passive transfer of EBV IgG from mother to child can produce a false positive in infants less than 1 year of age. ${ }^{57}$

\section{Posttransplant testing}

Quantitative EBV viral load: According to a recent recommendation, ${ }^{51,57}$ QNAT for EBV should be performed in children at high risk of primary EBV infection and PTLD development, including in EBVmismatched children (EBV D+, R-) once in the first week after transplant, at least monthly for the first 3-6 months, and then every 3 months for the first year post transplant, and after treatment for acute rejection. Quantitative EBV viral load using assays calibrated to the WHO standard for EBV DNA is recommended. ${ }^{57}$ There is currently no consensus on the exact threshold level to start treatment. There is no evidence that surveillance is beneficial in patients who are EBV $R+.{ }^{57}$

Tissue biopsy: EBV can be detected in specific organ involvement. In some settings, tissue biopsy is required to diagnose EBV disease and PTLDs, as defined by the WHO. 66

EBV serology: Anti-VCA and anti-EBNA IgM are used to diagnose primary infection in immunocompetent hosts, but the response in immunocompromised hosts, including posttransplant hosts, is delayed. . $^{3,56,57}$ Therefore, EBV serology is not useful for the diagnosis of early EBV infection, and the detection of EBV DNAemia according to EBV viral load is preferable. ${ }^{2}$ In addition, children who are EBV-naïve pre transplantation should undergo EBV IgG detection annually to determine their risk of developing primary EBV infection. ${ }^{57}$

\section{Treatment}

A reduction in immunosuppressive drugs is recommended when there is evidence of increasing EBV viral load, EBV disease or PTLDs, but this increases the risk of allograft rejection. ${ }^{3,51}$ A persistently high EBV viral load should be reevaluated for PTLDs. ${ }^{3,67}$ Cessation of immunosuppressive drugs might be necessary in some cases of PTLDs. ${ }^{51}$ To date, there are no conclusive data on the role of antiviral therapy in PTLDs.

\section{Prevention}

Although a universal antiviral prophylaxis strategy in high-risk EBV children (EBV D+R-) is used in some transplant centers, there are no sufficient data to support the routine use of prophylaxis to prevent either primary EBV infection or PTLDs. ${ }^{3,68-70}$ A recent meta-analysis ${ }^{71}$ did not demonstrate a benefit of antiviral prophylaxis in reducing the incidence of PTLDs. Therefore, the use of universal prophylaxis in EBV mismatches is not recommended. ${ }^{57}$ EBV viral load surveillance and preemptive therapy are recommended in EBVmismatched patients. ${ }^{57,61,62,72}$ Initial preemptive therapy involves a reduction in immunosuppressive drugs. ${ }^{73}$ The role of antiviral therapy, IVIG, or conversion to an mTOR inhibitor or rituximab is uncertain. ${ }^{57,73}$ Research and development of EBV vaccines are ongoing; there are currently no EBV vaccine options available. ${ }^{74-76}$

\section{Coronavirus-19 (COVID-19)}

The number of kidney transplantation procedures has decreased during the COVID-19 pandemic. ${ }^{77}$ COVID-19 is caused by SARs-CoV-2 infection. The overall deceased donor transplantation rates during the COVID-19 outbreak in France and the USA were $90.6 \%$ and $51.1 \%$, respectively. ${ }^{77} \mathrm{~A}$ recent study demonstrated that patients who were waitlisted for kidney transplantation had an increased risk of hospitalization and mortality. ${ }^{78}$ The first concern regarding kidney transplantation are the immunosuppressive status of recipients and the risk for COVID-19. The second concern is that there might be inadequate equipment, medical personnel, and intensive care unit resources post kidney transplantation. The third concern is the risk of potential transmission of COVID-19 from a kidney donor to a recipient. Almost all studies on COVID-19 among transplant recipients have been conducted in adults.

\section{Clinical features}

The most common presentations are similar to those in nontransplant patients and include fever, cough, dyspnea, and diarrhea. ${ }^{79-81}$ In addition, Iymphopenia is common in transplant recipients. ${ }^{80,81}$ However, transplant recipients have more rapid clinical progression and higher mortality than nontransplant patients. ${ }^{80,81}$ Thirtyday mortality was approximately $20-23 \%$ in hospitalized adult recipients. ${ }^{81,82}$

The criteria for testing for COVID-19 in kidney transplant recipients are similar to those in nontransplant patients. ${ }^{83}$ Routine screening of asymptomatic kidney transplant recipients is not recommended.

\section{Diagnosis}

All donors and recipients are recommended to undergo COVID-19 screening to prevent donor-derived infection and adjust the immunosuppressive drug regimen. Reverse-transcriptase polymerase chain reaction (RT$\mathrm{PCR}$ ) assays of respiratory tract specimens should be 
used for screening. ${ }^{84,85}$ This assay has high sensitivity, with detection ranging from 100 to 1,000 copies, and high specificity. ${ }^{84}$ Antigen tests of nasopharyngeal swabs are generally less sensitive than RT-PCR but have a shorter turnaround time. ${ }^{86}$

\section{Treatment}

General management in kidney transplant recipients is similar to that in nontransplant patients. ${ }^{87}$ The general approach is to reduce immunosuppressive drugs in patients with moderate to severe infection, but the optimal strategy is not well defined. ${ }^{79,81,87,88}$ Many observational studies suggest decreasing or withdrawing antimetabolite drugs such as mycophenolate mofetil and azathioprine. ${ }^{79-81,88}$

Several COVID-19 drugs have potential drug-drug interactions with immunosuppressive drugs, including tacrolimus, cyclosporine, mycophenolate mofetil, everolimus, and sirolimus, so therapeutic drug monitoring (TDM) is recommended. ${ }^{89}$

\section{Conclusion}

Viral infection is still a common opportunistic infection in children post kidney transplantation and must be considered in the differential diagnosis. Appropriate pretransplant screening and posttransplant surveillance may help with early diagnosis. In addition, appropriate antiviral prophylaxis and early management have improved patient and allograft outcomes.

Conflict of Interest Statement: The authors have no conflicts of interest to declare.

Financial Disclosure: The authors declared that this study has received no financial support.

Peer-review: Externally peer-reviewed.

\section{References}

1. Dharnidharka VR, Stablein DM, Harmon WE. Post-transplant infections now exceed acute rejection as cause for hospitalization: a report of the NAPRTCS. Am J Transplant. 2004;4:384-389. [CrossRef]

2. Kotton $\mathrm{CN}$, Fishman JA. Viral infection in the renal transplant recipient. J Am Soc Nephrol. 2005;16:1758-1774. [CrossRef]

3. Fishman JA. Infection in Organ Transplantation. Am J Transplant. 2017;17:856-879. [CrossRef]

4. Fishman JA. Infection in solid-organ transplant recipients. N Engl J Med. 2007;357:2601-2614. [CrossRef]

5. Smith JM, Dharnidharka VR. Viral surveillance and subclinica viral infection in pediatric kidney transplantation. Pediatr Nephrol. 2015;30:741-748. [CrossRef]

6. Comoli P, Ginevri F. Monitoring and managing viral infections in pediatric renal transplant recipients. Pediatr Nephrol. 2012;27:705-717. [CrossRef]

7. Al Khasawneh E, Araya CE, Dharnidharka VR. Missed vira surveillance testing visits associate with full blown viral diseases in children receiving kidney transplants. Pediatr Transplant. 2013;17:129-132. [CrossRef]

8. Weikert BC, Blumberg EA. Viral infection after renal transplantation: surveillance and management. Clin J Am Soc Nephrol. 2008;3:S76-S86. [CrossRef]

9. Gourishankar S, McDermid JC, Jhangri GS, Preiksaitis JK. Herpes zoster infection following solid organ transplantation: incidence, risk factors and outcomes in the current immunosuppressive era. Am J Transplant. 2004;4:108-115. [CrossRef]
10. Arthurs SK, Eid AJ, Pedersen RA, et al. Delayed-onset primary cytomegalovirus disease and the risk of allograft failure and mortality after kidney transplantation. Clin Infect Dis. 2008;46:840-846. [CrossRef]

11. Santos CA, Brennan DC, Fraser VJ, Olsen MA. Delayed-onset cytomegalovirus disease coded during hospital readmission after kidney transplantation. Transplantation. 2014;98:187-194. [CrossRef]

12. Chaiyapak T, Borges $\mathrm{K}$, Williams $\mathrm{A}$, et al. Incidence of Cytomegalovirus DNAemia in Pediatric Kidney Transplant Recipients After Cessation of Antiviral Prophylaxis. Transplantation. 2018;102:1391-1396. [CrossRef]

13. Ljungman $P$, Boeckh $M$, Hirsch $H H$, et al. Definitions of Cytomegalovirus Infection and Disease in Transplant Patients for Use in Clinical Trials. Clin Infect Dis. 2017;64:87-91. [CrossRef]

14. Kotton CN, Kumar D, Caliendo AM, et al. The Third International Consensus Guidelines on the Management of Cytomegalovirus in Solid-organ Transplantation. Transplantation. 2018;102:900931. [CrossRef]

15. Sester M, Gärtner BC, Sester U, Girndt M, Mueller-Lantzsch $\mathrm{N}$, Köhler $\mathrm{H}$. Is the cytomegalovirus serologic status always accurate? A comparative analysis of humoral and cellular immunity. Transplantation. 2003;76:1229-1230. [CrossRef]

16. Razonable RR, Hayden RT. Clinical utility of viral load in management of cytomegalovirus infection after solid organ transplantation. Clin Microbiol Rev. 2013;26:703-727. [CrossRef]

17. Hartmann A, Sagedal S, Hjelmesaeth J. The natural course of cytomegalovirus infection and disease in renal transplant recipients. Transplantation. 2006;82:S15-S17. [CrossRef]

18. Razonable RR, Humar A; AST Infectious Diseases Community of Practice. Cytomegalovirus in solid organ transplantation. Am J Transplant. 2013;13:93-106. [CrossRef]

19. Eid AJ, Arthurs SK, Deziel PJ, Wilhelm MP, Razonable RR. Clinical predictors of relapse after treatment of primary gastrointestinal cytomegalovirus disease in solid organ transplant recipients. Am J Transplant. 2010;10:157-161. [CrossRef]

20. Humar A, Mazzulli T, Moussa G, et al. Clinical utility of cytomegalovirus (CMV) serology testing in high-risk CMV D+/ R- transplant recipients. Am J Transplant. 2005;5:1065-1070. [CrossRef]

21. Razonable RR, Åsberg A, Rollag H, et al. Virologic suppression measured by a cytomegalovirus (CMV) DNA test calibrated to the World Health Organization international standard is predictive of CMV disease resolution in transplant recipients. Clin Infect Dis. 2013;56:1546-1553. [CrossRef]

22. Höcker B, Zencke S, Pape L, et al. Impact of Everolimus and Low-Dose Cyclosporin on Cytomegalovirus Replication and Disease in Pediatric Renal Transplantation. Am J Transplant. 2016;16:921-929. [CrossRef]

23. Pescovitz MD, Ettenger RB, Strife CF, et al. Pharmacokinetics of oral valganciclovir solution and intravenous ganciclovir in pediatric renal and liver transplant recipients. Transpl Infect Dis. 2010;12:195-203. [CrossRef]

24. Vaudry W, Ettenger $R$, Jara $P$, et al. Valganciclovir dosing according to body surface area and renal function in pediatric solid organ transplant recipients. Am J Transplant. 2009;9:636643. [CrossRef]

25. Höcker B, Zencke S, Krupka K, et al. Cytomegalovirus Infection in Pediatric Renal Transplantation and the Impact of Chemoprophylaxis With (Val-)Ganciclovir. Transplantation. 2016;100:862-870. [CrossRef]

26. Lamarche C, Orio J, Collette S, et al. BK Polyomavirus and the Transplanted Kidney: Immunopathology and Therapeutic Approaches. Transplantation. 2016;100:2276-2287. [CrossRef]

27. Hirsch $\mathrm{HH}$, Steiger J. Polyomavirus BK. Lancet Infect Dis. 2003;3:611-623. [CrossRef]

28. Gardner SD. Prevalence in England of antibody to human polyomavirus (B.k.). Br Med J. 1973;1:77-78. [CrossRef]

29. Antonsson A, Green AC, Mallitt KA, et al. Prevalence and stability of antibodies to the BK and JC polyomaviruses: a longterm longitudinal study of Australians. J Gen Virol. 2010;91:18491853. [CrossRef]

30. Knowles WA, Pipkin P, Andrews N, et al. Population-based study of antibody to the human polyomaviruses BKV and JCV and the simian polyomavirus SV40. J Med Virol. 2003;71:115-123. [CrossRef] 
31. Hirsch HH, Brennan DC, Drachenberg CB, et al. Polyomavirusassociated nephropathy in renal transplantation: interdisciplinary analyses and recommendations. Transplantation. 2005;79:12771286. [CrossRef]

32. Manzano Sánchez D, Jimeno García L, Manzano Sánchez D, et al. Renal Function Impairment in Kidney Transplantation: Importance of Early BK Virus Detection. Transplant Proc. 2019;51:350-352. [CrossRef]

33. Baksh FK, Finkelstein SD, Swalsky PA, Stoner GL, Ryschkewitsch CF, Randhawa P. Molecular genotyping of BK and JC viruses in human polyomavirus-associated interstitial nephritis after renal transplantation. $A m$ J Kidney Dis. 2001;38:354-365. [CrossRef]

34. Kazory A, Ducloux D, Chalopin JM, Angonin R, Fontanière $\mathrm{B}$, Moret $\mathrm{H}$. The first case of JC virus allograft nephropathy. Transplantation. 2003;76:1653-1655. [CrossRef]

35. Hirsch HH, Randhawa P; AST Infectious Diseases Community of Practice. BK polyomavirus in solid organ transplantation. Am J Transplant. 2013;13:179-188. [CrossRef]

36. Drachenberg CB, Hirsch HH, Papadimitriou JC, et al. Polyomavirus $\mathrm{BK}$ versus $\mathrm{JC}$ replication and nephropathy in renal transplant recipients: a prospective evaluation. Transplantation. 2007;84:323-330. [CrossRef]

37. Thangaraju S, Gill J, Wright A, Dong J, Rose C, Gill J. Risk Factors for BK Polyoma Virus Treatment and Association of Treatment With Kidney Transplant Failure: Insights From a Paired Kidney Analysis. Transplantation. 2016;100:854-861. [CrossRef]

38. Hirsch HH, Knowles W, Dickenmann M, et al. Prospective study of polyomavirus type BK replication and nephropathy in renal-transplant recipients. N Engl J Med. 2002;347:488-496. [CrossRef]

39. Imlay H, Whitaker K, Fisher CE, Limaye AP. Clinical characteristics and outcomes of late-onset BK virus nephropathy in kidney and kidney-pancreas transplant recipients. Transpl Infect Dis. 2018;20:e12928. [CrossRef]

40. Kamal M, Govil A, Anand M, Abu Jawdeh BG, Shah S. Severe BK polyomavirus-induced hemorrhagic cystitis in a kidney transplant recipient with the absence of renal allograft involvement. Transpl Infect Dis. 2018;20:10.1111/tid.12814. [CrossRef]

41. Nankivell BJ, Renthawa J, Jeoffreys N, et al. Clinical Utility of Urinary Cytology to Detect BK Viral Nephropathy. Transplantation. 2015;99:1715-1722. [CrossRef]

42. Zhong S, Zheng HY, Suzuki M, et al. Age-related urinary excretion of $\mathrm{BK}$ polyomavirus by nonimmunocompromised individuals. J Clin Microbiol. 2007;45:193-198. [CrossRef]

43. Laskin BL, Goebel J. Cost-efficient screening for BK virus in pediatric kidney transplantation: a single-center experience and review of the literature. Pediatr Transplant. 2010;14:589-595. [CrossRef]

44. Nickeleit V, Klimkait T, Binet IF, et al. Testing for polyomavirus type BK DNA in plasma to identify renal-allograft recipients with viral nephropathy. N Engl J Med. 2000;342:1309-1315. [CrossRef]

45. Madden K, Janitell C, Sower D, Yang S. Prediction of BK viremia by urine viral load in renal transplant patients: An analysis of BK viral load results in paired urine and plasma samples. Transpl Infect Dis. 2018;20:e12952. [CrossRef]

46. Nankivell BJ, Renthawa J, Sharma RN, Kable K, O'Connell PJ, Chapman JR. BK Virus Nephropathy: Histological Evolution by Sequential Pathology. Am J Transplant. 2017;17:2065-2077. [CrossRef]

47. Nickeleit V, Singh HK, Randhawa $P$, et al. The Banff Working Group Classification of Definitive Polyomavirus Nephropathy: Morphologic Definitions and Clinical Correlations. J Am Soc Nephrol. 2018;29:680-693. [CrossRef]

48. Atsumi H, Asaka M, Kimura S, et al. A case of second renal transplantation with acute antibody-mediated rejection complicated with BK virus nephropathy. Clin Transplant. 2010;24:35-38. [CrossRef]

49. McGilvray ID, Lajoie G, Humar A, Cattral MS. Polyomavirus infection and acute vascular rejection in a kidney allograft: coincidence or mimicry? Am J Transplant. 2003;3:501-504. [CrossRef]

50. Nickeleit V, Hirsch HH, Zeiler M, et al. BK-virus nephropathy in renal transplants-tubular necrosis, MHC-class II expression and rejection in a puzzling game. Nephrol Dial Transplant. 2000;15:324-332. [CrossRef]
51. Kidney Disease: Improving Global Outcomes (KDIGO) Transplant Work Group. KDIGO clinical practice guideline for the care of kidney transplant recipients. Am J Transplant. 2009;9:S1-S155. [CrossRef]

52. Baek CH, Kim H, Yu H, Yang WS, Han DJ, Park SK. Risk Factors of Acute Rejection in Patients with BK Nephropathy After Reduction of Immunosuppression. Ann Transplant. 2018;23:704-712. [CrossRef]

53. Josephson MA, Gillen D, Javaid B, et al. Treatment of renal allograft polyoma BK virus infection with leflunomide. Transplantation. 2006;81:704-710. [CrossRef]

54. Chong AS, Zeng $\mathrm{H}$, Knight DA, et al. Concurrent antiviral and immunosuppressive activities of leflunomide in vivo. $A m \mathrm{~J}$ Transplant. 2006;6:69-75. [CrossRef]

55. Kayler LK, Batal I, Mohanka R, et al. Antirejection treatment in kidney transplant patients with BK viruria. Transplantation. 2008;86:797-803. [CrossRef]

56. Odumade OA, Hogquist KA, Balfour HH Jr. Progress and problems in understanding and managing primary Epstein-Barr virus infections. Clin Microbiol Rev. 2011;24:193-209. [CrossRef]

57. Allen UD, Preiksaitis JK; AST Infectious Diseases Community of Practice. Post-transplant lymphoproliferative disorders, EpsteinBarr virus infection, and disease in solid organ transplantation: Guidelines from the American Society of Transplantation Infectious Diseases Community of Practice. Clin Transplant. 2019;33:e13652. [CrossRef]

58. Hanto DW. Classification of Epstein-Barr virus-associated posttransplant lymphoproliferative diseases: implications for understanding their pathogenesis and developing rational treatment strategies. Annu Rev Med. 1995;46:381-394. [CrossRef]

59. Colombini E, Guzzo I, Morolli F, et al. Viral load of EBV DNAemia is a predictor of EBV-related post-transplant Iymphoproliferative disorders in pediatric renal transplant recipients. Pediatr Nephrol. 2017;32:1433-1442. [CrossRef]

60. Faull RJ, Hollett P, McDonald SP. Lymphoproliferative disease after renal transplantation in Australia and New Zealand. Transplantation. 2005;80:193-197. [CrossRef]

61. Caillard S, Lamy FX, Quelen C, et al. Epidemiology of posttransplant lymphoproliferative disorders in adult kidney and kidney pancreas recipients: report of the French registry and analysis of subgroups of lymphomas. Am J Transplant. 2012;12:682-693. [CrossRef]

62. Peters AC, Akinwumi MS, Cervera $C$, et al. The Changing Epidemiology of Posttransplant Lymphoproliferative Disorder in Adult Solid Organ Transplant Recipients Over 30 Years: A Single-center Experience. Transplantation. 2018;102:1553-1562. [CrossRef]

63. Cockfield SM. Identifying the patient at risk for post-transplant lymphoproliferative disorder. Transpl Infect Dis. 2001;3:70-78. [CrossRef]

64. Caillard S, Dharnidharka V, Agodoa L, Bohen E, Abbott K. Posttransplant lymphoproliferative disorders after renal transplantation in the United States in era of modern immunosuppression. Transplantation. 2005;80:1233-1243. [CrossRef]

65. Hosseini-Moghaddam SM, Alhomayeed B, Soliman N, Weir MA, House AA. Primary Epstein-Barr virus infection, seroconversion, and post-transplant lymphoproliferative disorder in seronegative renal allograft recipients: a prospective cohort study. Transpl Infect Dis. 2016;18:423-430. [CrossRef]

66. Swerdlow SH, Campo E, Pileri SA, et al. The 2016 revision of the World Health Organization classification of lymphoid neoplasms. Blood. 2016;127:2375-2390. [CrossRef]

67. Bingler MA, Feingold B, Miller SA, et al. Chronic high EpsteinBarr viral load state and risk for late-onset posttransplant lymphoproliferative disease/lymphoma in children. Am J Transplant. 2008;8:442-445. [CrossRef]

68. Green M, Michaels MG. Epstein-Barr virus infection and posttransplant lymphoproliferative disorder. $\mathrm{Am} \mathrm{J}$ Transplant. 2013;13:41-54. [CrossRef]

69. Höcker B, Böhm S, Fickenscher H, et al. (Val-)Ganciclovir prophylaxis reduces Epstein-Barr virus primary infection in pediatric renal transplantation. Transpl Int. 2012;25:723-731. [CrossRef]

70. Ville S, Imbert-Marcille BM, Coste-Burel M, et al. Impact of antiviral prophylaxis in adults Epstein-Barr Virus-seronegative kidney recipients on early and late post-transplantation lymphoproliferative disorder onset: a retrospective cohort study. Transpl Int. 2018;31:484-494. [CrossRef] 
71. AlDabbagh MA, Gitman MR, Kumar D, Humar A, Rotstein C Husain S. The Role of Antiviral Prophylaxis for the Prevention of Epstein-Barr Virus-Associated Posttransplant Lymphoproliferative Disease in Solid Organ Transplant Recipients: A Systematic Review. Am J Transplant. 2017;17:770-781. [CrossRef]

72. Sampaio MS, Cho YW, Shah T, Bunnapradist S, Hutchinson IV. Impact of Epstein-Barr virus donor and recipient serostatus on the incidence of post-transplant lymphoproliferative disorder in kidney transplant recipients. Nephrol Dial Transplant. 2012;27:2971-2979. [CrossRef]

73. San-Juan R, Manuel O, Hirsch $\mathrm{HH}$, et al. Current preventive strategies and management of Epstein-Barr virus-related post-transplant lymphoproliferative disease in solid organ transplantation in Europe. Results of the ESGICH Questionnairebased Cross-sectional Survey. Clin Microbiol Infect. 2015;21:604. e1-604.e6049. [CrossRef]

74. Allen UD. Epstein-barr virus vaccination of transplant candidates: light at the end of the tunnel?. Transplantation. 2009;88:976-977. [CrossRef]

75. Cohen JI. Vaccine Development for Epstein-Barr Virus. Adv Exp Med Biol. 2018;1045:477-493. [CrossRef]

76. Rees L, Tizard EJ, Morgan AJ, et al. A phase I trial of epsteinbarr virus gp350 vaccine for children with chronic kidney disease awaiting transplantation. Transplantation. 2009;88:1025-1029. [CrossRef]

77. Loupy A, Aubert O, Reese PP, Bastien O, Bayer F, Jacquelinet C. Organ procurement and transplantation during the COVID-19 pandemic. Lancet. 2020;395:e95-e96. [CrossRef]

78. Craig-Schapiro R, Salinas T, Lubetzky M, et al. COVID-19 outcomes in patients waitlisted for kidney transplantation and kidney transplant recipients. Am J Transplant. 2021;21:15761585. [CrossRef]

79. Pereira MR, Mohan S, Cohen DJ, et al. COVID-19 in solid organ transplant recipients: Initial report from the US epicenter. $A m \mathrm{~J}$ Transplant. 2020;20:1800-1808. [CrossRef]
80. Akalin E, Azzi Y, Bartash R, et al. Covid-19 and Kidney Transplantation. N Engl J Med. 2020;382:2475-2477. [CrossRef]

81. Caillard S, Anglicheau D, Matignon M, et al. An initial report from the French SOT COVID Registry suggests high mortality due to COVID-19 in recipients of kidney transplants. Kidney Int. 2020;98:1549-1558. [CrossRef]

82. Kates OS, Haydel BM, Florman SS, et al. COVID-19 in solid organ transplant: A multi-center cohort study. Clin Infect Dis. 2020; ciaa1097. [CrossRef]

83. Weiss MJ, Lalani J, Patriquin-Stoner C, et al. Summary of International Recommendations for Donation and Transplantation Programs During the Coronavirus Disease Pandemic. Transplantation. 2021;105:14-17. [CrossRef]

84. Fang FC, Naccache SN, Greninger AL. The Laboratory Diagnosis of Coronavirus Disease 2019- Frequently Asked Questions. Clin Infect Dis. 2020;71:2996-3001. [CrossRef]

85. Cheng MP, Papenburg J, Desjardins M, et al. Diagnostic Testing for Severe Acute Respiratory Syndrome-Related Coronavirus 2: A Narrative Review. Ann Intern Med. 2020;172:726-734. [CrossRef]

86. Weissleder R, Lee H, Ko J, Pittet MJ. COVID-19 diagnostics in context. Sci Transl Med. 2020;12:eabc1931. [CrossRef]

87. Banerjee D, Popoola J, Shah S, Ster IC, Quan V, Phanish M. COVID-19 infection in kidney transplant recipients. Kidney Int. 2020;97:1076-1082. [CrossRef]

88. Zhong Z, Zhang Q, Xia $\mathrm{H}$, et al. Clinical characteristics and immunosuppressant management of coronavirus disease 2019 in solid organ transplant recipients. Am J Transplant. 2020;20:19161921. [CrossRef]

89. Elens L, Langman LJ, Hesselink DA, et al. Pharmacologic Treatment of Transplant Recipients Infected With SARS-CoV-2: Considerations Regarding Therapeutic Drug Monitoring and Drug-Drug Interactions. Ther Drug Monit. 2020;42:360-368. [CrossRef] 